\title{
Faktor-faktor yang Mempengaruhi Keputusan Petani Mangga dalam Pemilihan Pasar di Kabupaten Indramayu
}

\section{Factors Affecting Mango Farmers Decisions in Market Selection in Indramayu District}

\author{
Rani Andriani ${ }^{1}$, Budi Kusumo, Elly Rasmikayati, Gema Wibawa Mukti, Sri Fatimah \\ Program Studi Agribisnis Fakultas Pertanian Universitas Padjadjaran \\ Jl. Raya Jatinangor Sumedang Km. 21
}

\begin{abstract}
Increasing domestic demand for mangoes in recent years has increased rapidly, not only in terms of quantity but also in terms of quality of mango, especially for modern markets. But only a small part of the mango which could entered the modern market. Understanding of farmers' access to markets is needed to increase farmers' capacity as an effort to improve farmers' welfare. The purpose of this research were to: 1) Analyze socioeconomic characteristics of mango farmers in Indramayu Regency; 2) Analyze the mango marketing channel in Indramayu District; 3) Analyze the factors that influence the decision of mango farmers in market selection in Indramayu District. This research is a quantitative research with 130 mango farmers who were taken by using multi stage random sampling. Data were analyzed descriptively as well as logistic regression analysis. The results showed that most of the farmers were in productive age, had completed primary school education, had $<100$ trees, never participated in the activity, did not join to farmers group and partnership in marketing. Most farmers market their crops to collecting traders. The level of education of farmers, frequency of extension activities, access to information about mango's market, quality requirements, the percentage of mango of good quality and the attachment of farmers to certain financing sources are the factors that significantly influence the farmer's decision in choosing the market. The role of farmer groups is needed to collect farmers in marketing their crops with profitable systems for farmers.
\end{abstract}

Keywords: decision, influence, market, mango farmers

\begin{abstract}
Abstrak
Peningkatan permintaan mangga di dalam negeri beberapa tahun belakangan ini meningkat pesat, bukan hanya dari sisi kuantitas saja tetapi juga dari sisi kualitas buah mangga, terutama untuk pasar modern. Namun baru sebagian kecil mangga produksi petani yang berhasil memasuki pasar modern. Pemahaman mengenai akses petani ke pasar diperlukan untuk meningkatkan kapasitas petani sebagai upaya peningkatan kesejahteraan petani. Tujuan dari penelitian ini adalah untuk : 1) Menganalisis karakteristik sosial ekonomi petani mangga di Kabupaten Indramayu; 2) Menganalisis saluran pemasaran mangga di Kabupaten Indramayu; 3) Menganalisis faktor-faktor yang mempengaruhi keputusan petani mangga dalam pemilihan pasar di Kabupaten Indramayu. Penelitian ini merupakan penelitian kuantitatif. Responden dalam penelitian ini adalah 130 orang petani mangga yang diambil secara acak. Data dianalisis secara deskriptif serta analisis regresi logistic. Hasil penelitian menunjukan sebagian besar petani berada pada usia produktif, menempuh pendidikan tamat sekolah dasar, memiliki $<100$ pohon, tidak pernah mengikuti kegiatan, tidak tergabung dalam kelompok tani dan kemitraan dalam pemasaran. Sebagian besar petani memasarkan hasil panennya pada pedagang pengumpul. Tingkat pendidikan petani, frekuensi mengikuti kegiatan penyuluhan, akses informasi mengenai pemasaran mangga, kemudahan syarat memasuki pasar, presentase hasil panen yang berkualitas baik serta keterikatan petani terhadap sumber pembiayaan tertentu merupakan faktor-faktor yang berpengaruh secara signifikan terhadap keputusan petani dalam memilih pasar. Peran kelompok tani diperlukan untuk menghimpun petani dalam memasarkan hasil panennya dengan sistem yang menguntungkan bagi petani.
\end{abstract}

Kata kunci: keputusan, pasar, pengaruh, petani mangga

\footnotetext{
${ }^{1}$ Korespondensi penulis

E-mail: raniandriani081@gmail.com
} 


\section{Pendahuluan}

Mangga merupakan salah satu komoditas unggulan dan bernilai ekonomis tinggi di Indonesia. Data proyeksi produksi mangga di Indonesia menunjukkan selama kurun waktu tahun 2014-2018 produksi mangga terus mengalami peningkatan, pada tahun 2018 produksi mangga diproyeksikan sebanyak 2.888.160 ton (Pusat Data dan Informasi Kementrian Pertanian, 2014) ${ }^{2}$.Di Indonesia, mangga banyak diusahakan di Pulau Jawa. Jawa Barat merupakan daerah penghasil mangga ketiga terbesar di Indonesia, setelah Provinsi Jawa Timur dan Jawa Tengah, dilihat dari luas panen dan volume produksi (Pusat Data dan Informasi Kementrian Pertanian, 2014).

Tabel 1. Produksi Mangga di Daerah Sentra Mangga Jawa Barat

\begin{tabular}{lcccccc}
\hline \multirow{2}{*}{ Kabupaten } & \multicolumn{7}{c}{ Produksi Mangga (Ton) } \\
\cline { 2 - 8 } & $\mathbf{2 0 1 0}$ & $\mathbf{2 0 1 1}$ & $\mathbf{2 0 1 2}$ & $\mathbf{2 0 1 3}$ & $\mathbf{2 0 1 4}$ & $\mathbf{2 0 1 5}$ \\
\hline Kuningan & 5.528 & 44.868 & 39.377 & 32.406 & 23.329 & 32.108 \\
\hline Cirebon & 13.077 & 55.981 & 62.053 & 30.945 & 51.661 & 37.443 \\
\hline Majalengka & 16.431 & 43.280 & 48.521 & 10.243 & 57.172 & 64.394 \\
\hline Sumedang & 17.534 & 21.169 & 29.008 & 23.607 & 20.633 & 23.491 \\
\hline Indramayu & 35.826 & 63.057 & 68.506 & 84.788 & 72.436 & 69.737 \\
\hline
\end{tabular}

Sumber : BPS, 2015

Daerah penghasil mangga di Provinsi Jawa Barat diantaranya adalah Kabupaten Cirebon, Indramayu, Kuningan, Majalengka dan Sumedang dimana Kabupaten Indramayu merupakan penghasil mangga terbesar di Jawa Barat. Namun pada kurun waktu tahun 2014-2015 produksi mangga di Kabupaten Indramayu mengalami penurunan (Tabel 1), hal ini disebabkan banyaknya tanaman mangga yang terserang hama penyakit yang berdampak pada tingkat produksi mangga.

Selain permasalahan produksi yang menurun, permasalahan umum yang dihadapi petani mangga adalah kualitas produk yang belum seragam serta produktifitas hasil yang masih rendah. Salah satu akar penyebab dari persoalan ini adalah masih lemahnya kapasitas dan kapabilitas dari petani itu sendiri (Deliana, 2012).Padahal di sisi permintaan, konsumsi mangga untuk rumah tangga diperkirakan akan meningkat sebesar $6,90 \%$ setiap tahunnya (Pusat Data dan Informasi Kementrian Pertanian, 2014).

Peningkatan permintaan mangga di dalam negeri bukan hanya dari sisi kuantitas saja tetapi juga dari sisi kualitas buah mangga, terutama untuk pasar modern. Saat ini pertumbuhan pasar modern sangat pesat, Noor (2013) menyebutkan pasar modern di Indonesia tumbuh $10-15 \%$ setiap tahunnya. Namun sayangnya, secara nasional jumlah mangga yang mendapatkan akses ke pasar modern belum mencapai target ideal dengan angka rata-rata masih dibawah $15 \%$ dari total produksi setiap tahunnya.Beberapa hasil penelitian juga menunjukkan bahwa hanya sebagian kecil petani hortikultura yang dapat menembus pasar modern (Natawidjadja et al, 2007; Sulistyowati et al, 2013). Peningkatan akses bagi petani untuk dapat terhubung dengan pasar modern mendapat perhatian besar beberapa tahun terakhir ini. Komersialisasi produk oleh petani kecil ke pasar modern dinilai dapat mengurangi tingkat kemiskinan pedesaan di negara berkembang (Collier dan Dercon, 2014; Barrett et al, 2010).

Petani yang dapat memasuki pasar modern masih terbatas pada petani yang melakukan investasi pada sistem produksi nya dan memiliki asset pengetahuan tentang teknologi Natawidjaja et al (2007), memiliki fasilitas khusus seperti fasilitas

\footnotetext{
${ }^{2}$ Data merupakan hasil proyeksi yang dilakukan dengan analisis deret waktu menggunakan metode Winters.
} 
penyimpanan (Farina dan Reardon, 2000), sehingga petani dapat menghasilkan produk dengan kualitas yang diinginkan oleh pasar modern. Pada kenyataannya dalam agribisnis mangga, fenomena yang ditemui sebagian besar petani masih kesulitan dalam hal permodalan, sehingga sulit untuk melakukan investasi dalam sub sistem produksi. Tidak hanya itu, kesulitan dalam hal permodalan juga mengakibatkan petani terikat perjanjian dengan pedagang pengumpul karena adanya ikatan modal dalam sarana produksi yang secara tidak langsung juga merupakan alat pengikat dalam kegiatan pemasaran (Anugrah 2009).

Keputusan petani untuk memilih pasar bagi produk mangganya dipengaruhi oleh berbagai faktor. Hasil penelitian (Data primer, 2017) menunjukkandi Kabupaten Indramayu sebagian besar petani memilih untuk memasarkan hasil panen nya ke lembaga informal (bandar, tengkulak), hanya sebagian kecil petani $(6,92 \%)$ yang memasarkan hasil panennya ke lembaga formal (pasar modern dan eksportir). Natawidjadja (2012) menyebutkan dukungan pelayanan permodalan yang ditawarkan oleh bandar atau tengkulak menjadi pertimbangan tersendiri bagi petani untuk menjual hasil panen nya pada bandar atau tengkulak. Beberapa hasil penelitian juga menunjukkan bahwa menjelaskan orientasi pasar petani dipengaruhi oleh sistem pembiayaan dan akses terhadap informasi (Sulistyowati et al, 2013; Abafita et al, 2016; Melesse, 2016).

Pemahaman mengenai akses pasar petani mangga beserta faktor-faktor yang mempengaruhinya perlu dilakukan dalam upaya memperbaiki dan meningkatkan perilaku agribisnis petani secara menyeluruh dari mulai proses produksi hingga pemasaran. Berdasarkan pemaparan di atas, tujuan dari penelitian ini adalah untuk : 1) Menganalisis karakteristik sosial ekonomi petani mangga di Kabupaten Indramayu; 2) Menganalisis saluran pemasaran mangga di Kabupaten Indramayu; 3) Menganalisis faktor-faktor yang mempengaruhi keputusan petani mangga dalam pemilihan pasar di Kabupaten Indramayu.

\section{Metode Penelitian}

Penelitian ini merupakan bagian dari penelitian payung yang berjudul " Era Globalisasi:Upaya Peningkatan Kapasaitas Petani Mangga Di Pasar Modern Ditinjau Dari Dinamika Agribisnis Dan Penguasaan Lahannya". Penelitian dilakukan pada bulan April - November 2017.

Penelitian dilakukan dengan metode Surveyeksplanatory, dengan pengambilan sampel Multi-stage random sampling. Tahapannya adalahmemilih satu kecamatan yang merupakan sentra mangga di Kabupaten Indramayu(yaitu Kecamatan Cikedung), selanjutnya menentukan dua desa sentra mangga (Desa Jatisura dan Cikedung). Pada masing-masing desa diambil responden petani secara acak sebanyak65 responden, sehingga jumlah total responden petani mangga adalah sebanyak 130 orang.

Sampel petani mangga dipilih dari sampling frame didasarkan pada listing populasi petani mangga dari BPS yang diperbaharui setiap 10 tahun. BPS membagi wilayah berdasarkan sensus block yang merupakan pembagian lebih kecil dari desa/kelurahan, setiap sensus block terdiri dari 80-120 keluarga. BPS mendefinisikan petani mangga adalah keluarga petani yang memiliki 4 pohon mangga atau lebih.

Variabel bebas dalam penelitian ini adalah : 1) Karakteristik sosial ekonomi petani yang meliputi umur, tingkat pendidikan, jumlah pohon yang diusahakan, pengalaman usahatani mangga, frekuensi mengikuti kegiatan penyuluhan, keanggotaan dalam kelompok tani, serta kemitraan dalam pemasaran; 2) Akses petani terhadap informasi dan pasar, yang meliputi akses terhadap informasi mengenai budidaya mangga, akses terhadap informasi mengenai pemasaran mangga, akses informasi mengenai harga mangga, kondisi jalan ke 
kebun, serta kemudahan mengakses pasar yang dituju; 3) Persyaratan memasuki pasar, yang meliputi syarat kualitas produk, syarat kuantitas produk, syarat kontinyuitas produk, persentase hasil panen yang berkualitas baik (grade A), serta keterikatan terhadap lembaga tertentu dalam pemasaran mangga. Sedangkan yang menjadi variabel terikat adalah jenis pasar yang dipilih oleh petani dalam memasarkan hasil panen nya (formal / informal).

Untuk menganalisis karakteristik sosial ekonomi petani mangga serta saluran pemasaran mangga di Kabupaten Indramayu, digunakan análisis deskriptif. Sedangkan untuk menganalisis faktor-faktor yang mempengaruhi keputusan petani mangga dalam memilih saluran pemasaran dilakukan dengan análisis regresi logistik, dengan persamaan sebagai berikut :

$$
\begin{gathered}
P(x)=\frac{\mathrm{e}^{\alpha+\beta 1 \times 1+\beta 2 \times 2+\beta 3 \times 3+\beta 4 \times 4+\ldots+\beta 18 \times 18+}}{\underline{\varepsilon}} \\
1+\mathrm{e}^{\alpha+\beta 1 \times 1+\beta 2 \times 2+\beta 3 \times 3+\beta 4 \times 4+. .+\beta 18 \times 18+\varepsilon}
\end{gathered}
$$

Keterangan :

$\mathrm{P}(\mathrm{x})=$ pasar petani mangga

0 =informal (tengkulak atau bandar, 1= formal (pasar modern atau eksportir)

$\alpha=$ Konstanta

$\beta=$ Koefisien regresi

$\mathrm{e}=$ Eksponen

$\varepsilon=$ Error (Galat)

$\mathrm{X}_{1}=$ umur

$\mathrm{X}_{2}=$ tingkat pendidikan

$\mathrm{X}_{3}=$ jumlah pohon

$\mathrm{X}_{4}=$ pengalaman usahatani mangga

$\mathrm{X}_{5}=$ frekuensi mengikuti keg penyuluhan

$\mathrm{X}_{6}=$ keanggotaan dalam kelompok tani $(1=$ ya, $0=$ tidak $)$

$\mathrm{X}_{7}=$ bermitra dalam pemasaran $(1=$ ya, $0=$ tidak $)$

$\mathrm{X}_{8}=$ akses terhadap informasi mengenai budidaya mangga

$\mathrm{X}_{9}=$ akses terhadap informasi mengenai pemasaran mangga
$\mathrm{X}_{10}=$ Mendapatkan informasi mengenai harga mangga $(1=$ ya, $0=$ tidak $)$

$\mathrm{X}_{11}=$ kondisi jalan ke kebun

$\mathrm{X}_{12}=$ kemudahan mengakses pasar

$\mathrm{X}_{13}=$ syarat kualitas produk

( 1 = ya, 0 = tidak $)$

$\mathrm{X}_{14}=$ syarat kuantitas produk

$(1=$ ya, 0 = tidak $)$

$\mathrm{X}_{15}=$ syarat kontinyuitas produk

$$
\text { ( } 1 \text { = ya, } 0=\text { tidak })
$$

$\mathrm{X}_{16}=$ persentase hasil panen yang berkualitas baik (grade A)

$\mathrm{X}_{17}=$ Keterikatan pada lembaga tertentu

$(1=$ ya, $0=$ tidak $)$

\section{Hasil dan Pembahasan}

\section{Karakteristik Sosial Ekonomi Responden}

Karakteristik sosial ekonomi petani mangga di Kabupaten Indramayu dapat dilihat pada Tabel 1. Sebagian besar responden $(95,38 \%)$ berada pada umur produktif, BPS mendefinisikan kelompok umur produktif adalah penduduk yang berusia antara $15-64$ tahun, dan rata-rata umur responden adalah 45,1 tahun.

Tingkat pendidikan akan membentuk sikap mental petani dalam menerima hal yang baru, seperti kemampuan mengakses informasi dan kemampuan manajerial (Caswell et al, 2011). Tingkat pendidikan responden tergolong rendah, separuh responden $(54,62 \%)$ hanya menempuh pendidikan hingga tingkat sekolah dasar, bahkan 12,31\% responden tidak pernah menempuh pendidikan formal.

BPS mengelompokkan petani mangga berdasarkan dengan kepemilikan pohon, petani yang memiliki 4-10 pohon dikategorikan sebagai petani halaman (backyard farmer). Sedangkan petani yang memiliki 11 pohon keatas dikategorikan sebagai petani kebun (commercial farmer). Berdasarkan kategori tersebut seluruh petani termasuk dalam kategori petani kebun. Dilihat dari pengalaman usahatani, sebagian besar responden $(60 \%)$ memiliki pengalaman usahatani kurang dari 10 tahun. 
Tabel 1. Karakteristik Sosial Ekonomi Responden

\begin{tabular}{|c|c|c|}
\hline 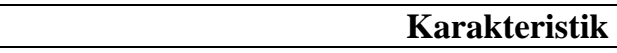 & n (orang) & $\%$ \\
\hline \multicolumn{3}{|l|}{ Umur } \\
\hline Produktif (15-64 tahun) & 124 & 95,38 \\
\hline Non Produktif (>64 tahun) & 6 & 4,62 \\
\hline Rata-rata umur 45,1 : tahun & & \\
\hline \multicolumn{3}{|l|}{ Tingkat pendidikan } \\
\hline Tidak Sekolah & 16 & 12,31 \\
\hline SD & 71 & 54,62 \\
\hline SMP & 28 & 21,54 \\
\hline SMA & 13 & 10,00 \\
\hline Diploma & 0 & 0 \\
\hline Sarjana & 2 & 1,53 \\
\hline \multicolumn{3}{|l|}{ Jumlah pohon yang dimiliki } \\
\hline$\leq 10$ & 0 & 0 \\
\hline $11-100$ & 52 & 40,00 \\
\hline $101-200$ & 61 & 4,92 \\
\hline $201-300$ & 17 & 13,08 \\
\hline \multicolumn{3}{|l|}{ Pengalaman usahatani (tahun) } \\
\hline $0-10$ & 78 & 60,00 \\
\hline $11-20$ & 44 & 33,85 \\
\hline $21-30$ & 6 & 4,62 \\
\hline $31-40$ & 1 & 0,77 \\
\hline $41-50$ & 0 & 0 \\
\hline$>50$ & 1 & 0,77 \\
\hline \multicolumn{3}{|c|}{ Frekuensi mengikuti kegiatan penyuluhan (per tahun) } \\
\hline tdk pernah & 104 & 80,00 \\
\hline $1-2 \mathrm{x}$ & 26 & 20,00 \\
\hline $3-6 x$ & 0 & 0 \\
\hline $7-10 x$ & 0 & 0 \\
\hline \multicolumn{3}{|l|}{ Keanggotaan dalam kelompok tani } \\
\hline Ya & 3 & 2,31 \\
\hline Tidak & 127 & 97,69 \\
\hline \multicolumn{3}{|l|}{ Bermitra dalam pemasaran mangga } \\
\hline $\mathrm{Ya}$ & 4 & 3,08 \\
\hline Tidak & 126 & 96,92 \\
\hline
\end{tabular}

Sebagian besar petani (80\%) mengaku tidak pernah mengikuti kegiatan penyuluhan, baik dari Dinas Pertanian ataupun instansi lainnya. Berdasarkan penuturan petani kegiatan penyuluhan saat ini mulai jarang dilakukan karena pemerintah menilai petani telah mampu melakukan usahataninya dengan mandiri. Namun bagi sebagian petani kegiatan penyuluhan masih dirasakan perlu karena masih terdapat permasalahan yang dirasakan oleh petani dan belum ditemukan solusinya.

Kelompok tani berfungsi sebagai wahana belajar, wahana kerjasama dan sebagai unit produksi agar para anggotanya dapat saling berbagi informasi, dan mengembangkan usaha, namun di lokasi penelitian sebagian besar petani $(97,69 \%)$ tidak tergabung dalam kelompok tani, Meskipun tidak tergabung dalam kelompok tani, petani tetap bisa memperoleh berbagai informasi dari petani lain, mulai dari perkembangan teknologi, pasar, hingga berbagai permasalahan yang dihadaoi dalam usahatani mangga. Nakano (2018) menjelaskan bahwa jaringan sosial antar petani dapat membantu petani untuk mengadopsi teknologi baru. Hubungan yang terjalin diantara petani memudahkan petani untuk memperoleh berbagai informasi. Dalam hal kemitraan, hanya sebagian kecil petani $(3,08 \%)$ yang menjalin kemitraan dengan perusahaan pemasok buah segar. Sebagian besar petani lebih memilih menjual 
hasil panennya langsung ke tengkulak atau bandar.

\section{Akses Petani terhadap Informasi dan Pasar}

Sebagian besar responden $(69,23 \%)$ menilai informasi mengenai teknis budidaya mangga mudah didapatkan (Tabel 2). Dalam era digital saat ini, informasi mudah didapatkan dari berbagai sumber, dan sebagian besar petani juga telah memanfaatkan perkembangan teknologi komunikasi untuk mencari informasi mengenai budidaya mangga.Dalam hal informasi mengenai pemasaran mangga, sebagian besar petani $(83,08 \%)$ menilai informasi mudah untuk didapatkan (Tabel 2). Lebih dari separuhpetani $(55,38 \%)$ menjual hasil panen nya ke tengkulak atau bandar, sementara $26,92 \%$ petani memilih untuk menjual mangga dengan sistem tebasan dan tidak melakukan panen sendiri. Umumnya tengkulak, bandar dan penebas yang membeli buah mangga petani adalah orang yang sudah petani kenal, sehingga petani merasa mudah dalam mendapatkan informasi mengenai pasar mangga dan juga merasa mudah dalam mengakses pasar yang selama ini menampung hasil panen petani.

Tabel 2. Sebaran Responden berdasarkan Akses Terhadap Informasi dan Pasar

\begin{tabular}{lrr}
\hline \multicolumn{1}{c}{ Akses terhadap Informasi dan Pasar } & n (orang) & \% \\
\hline Akses terhadap informasi budidaya mangga & 4 & 3,08 \\
\hline Sangat mudah & 90 & 69,23 \\
\hline Mudah & 33 & 25,38 \\
\hline Cukup sulit & 3 & 2,31 \\
\hline Sulit & 0 & 0 \\
\hline Sangat sulit & & \\
\hline Akses terhadap informasi pemasaran mangga & 18 & 13,85 \\
\hline Sangat mudah & 108 & 83,08 \\
\hline Mudah & 2 & 1,54 \\
\hline Cukup sulit & 2 & 1,54 \\
\hline Sulit & 0 & 0 \\
\hline Sangat sulit & & \\
\hline Mengetahui informasi mengenai harga mangga & 77 & 59,23 \\
\hline Ya & 53 & 40,77 \\
\hline Tidak & & \\
\hline Kemudahan mengakses pasar & 43 & 33,08 \\
\hline Sangat mudah & 82 & 63,08 \\
\hline Mudah & 0 & 0 \\
\hline Cukup sulit & 0 & 3,84 \\
\hline Sulit & 5 & 0 \\
\hline Sangat sulit & 0 & 86,92 \\
\hline Akses jalan ke kebun & & 13,08 \\
\hline Dapat dilewati mobil & 113 & \\
\hline Belum dapat dilewati mobil & 17 & \\
\hline
\end{tabular}

Lebih dari separuh responden $(59,23 \%)$ merasa selama ini mereka mendapatkan informasi yang cukup mengenai harga buah mangga di pasaran. Namun sebagian petani lain menilai kurang adanya transparansi harga buah mangga di pasaran. Ramadhani dan Rasmikayati (2017) menyebutkan bahwa petani kurang memiliki daya tawar dalam penentuan harga jual mangga ketika petani menjual hasil panennya pada tengkulak atau bandar. Natawidjadja (2010) menjelaskan bahwa pedagang (tengkulak atau bandar) memiliki informasi yang lebih baik mengenai harga karena mobilitas dan akses mereka ke pasar di kota, dan seringkali petani tidak mendapatkan informasi tersebut. Untuk mengatasi kekurangan informasi, petani biasanya berusaha mencari informasi harga di pasar lokal.

Mosher (1991) menjelaskan bahwa salah satu syarat pokok dalam pembangunan 
Tabel 3. Sebaran Responden berdasarkan Persyaratan Memasuki Pasar

\begin{tabular}{lcr}
\hline \multicolumn{1}{c}{ Karakteristik } & n (orang) & \% \\
\hline Syarat kualitas produk & & \\
\hline Ada & 71 & 54,62 \\
\hline Tidak ada & 59 & 45,38 \\
\hline Syarat kuantitas produk & & \\
\hline Ada & 0 & 0 \\
\hline Tidak ada & 130 & 100 \\
\hline Syarat kontinyuitas produk & 0 & 0 \\
\hline Ada & 130 & 100 \\
\hline Tidak ada & & \\
\hline Persentase hasil panen berkualitas baik (grade A) & 15 & 11,54 \\
\hline$\leq 50 \%$ & 115 & 88,46 \\
\hline$>50 \%$ & & \\
\hline Keterikatan modal pada lembaga tertentu & 56 & 43,08 \\
\hline Ya & 74 & 56,92 \\
\hline Tidak
\end{tabular}

pertanian adalah sarana dan prasarana transportasi yang memadai. Sebagian besar petani $(89,92 \%)$ menilai sarana jalan menuju ke kebun petani sudah baik. Kondisi jalan yang baik dan dapat dilalui oleh kendaraan roda empat, dirasakan memudahkan petani dalam menjalankan usahataninya.

\section{Saluran Pemasaran Mangga di Kabupaten Indramayu}

Varietas mangga yang banyak diusahakan oleh petani di Kabupaten Indramayu adalah mangga Gedong Gincu, Cengkir dan Harumanis. Sebagian besar petani mangga memasarkan hasil panennya ke lembaga informal (tengkulak atau bandar). Sebagian besar petani berpendapat bahwa tengkulak dan bandar adalah pasar yang paling mudah untuk diakses.Tengkulak dan bandar biasanya adalah orang yang sudah dikenal dekat oleh petani. Lebih lanjut, Natawidjaja (2010) menjelaskan bahwa ketika petani dan pedagang perantara membangun ikatan patronase perdagangan jangka panjang, hal tersebut mengikat secara informal sehingga tidak memungkinkan pedagang lain atau pedagang luar untuk memasuki pasar dengan mudah.

Ketika petani menjual hasil panennya pada tengkulak atau bandar, petani tidak perlu mengeluarkan biaya tranportasi untuk mengangkut hasil panen nya ke pasar, dan juga petani tidak perlu menanggung resiko kerusakan produk selama proses pengangkutan mangga dari kebun ke pasar. Jangka waktu pembayaran menjadi pertimbangan tersendiri bagi petani dalam memilih pasar. Tengkulak atau bandar membeli hasil panen petani dan membayarnya secara tunai, hal ini yang mendorong petani untuk memilih menjual mangga nya pada tengkulak atau bandar, karena petani memerlukan uang sebagai modal untuk perawatan pohon mangga.

Kemudahan syarat dalam transaksi juga mendorong petani untuk memilih pasar tertentu. Menurut sebagian petani, tidak terdapat persyaratan kualitas, kuantitas dan kontinyuitas produk apabila petani menjual produknya ke tengkulak atau bandar, kalaupun ada biasanya persyaratan kualitas produk tidak terlalu ketat (Tabel 3).

Tengkulak dan bandar biasanya menampung mangga petani dari semua gradedan tengkulak / bandar melakukan kegiatan sortasi serta grading baru kemudian menyalurkannya sesuai dengan pasar yang dituju (Gambar 1). Hanya sebagian kecil petani responden yang menjual hasil panennya dan menjalin kemitraan dengan lembaga pemasaran formal seperti pasar modern dan perusahaan pemasok buah segar yang akan memasarkan mangga ke pasar eksport dan supermarket (Gambar 1). Petani yang sudah mampu mengakses pasar modern dan pasar eksport adalah petani yang 


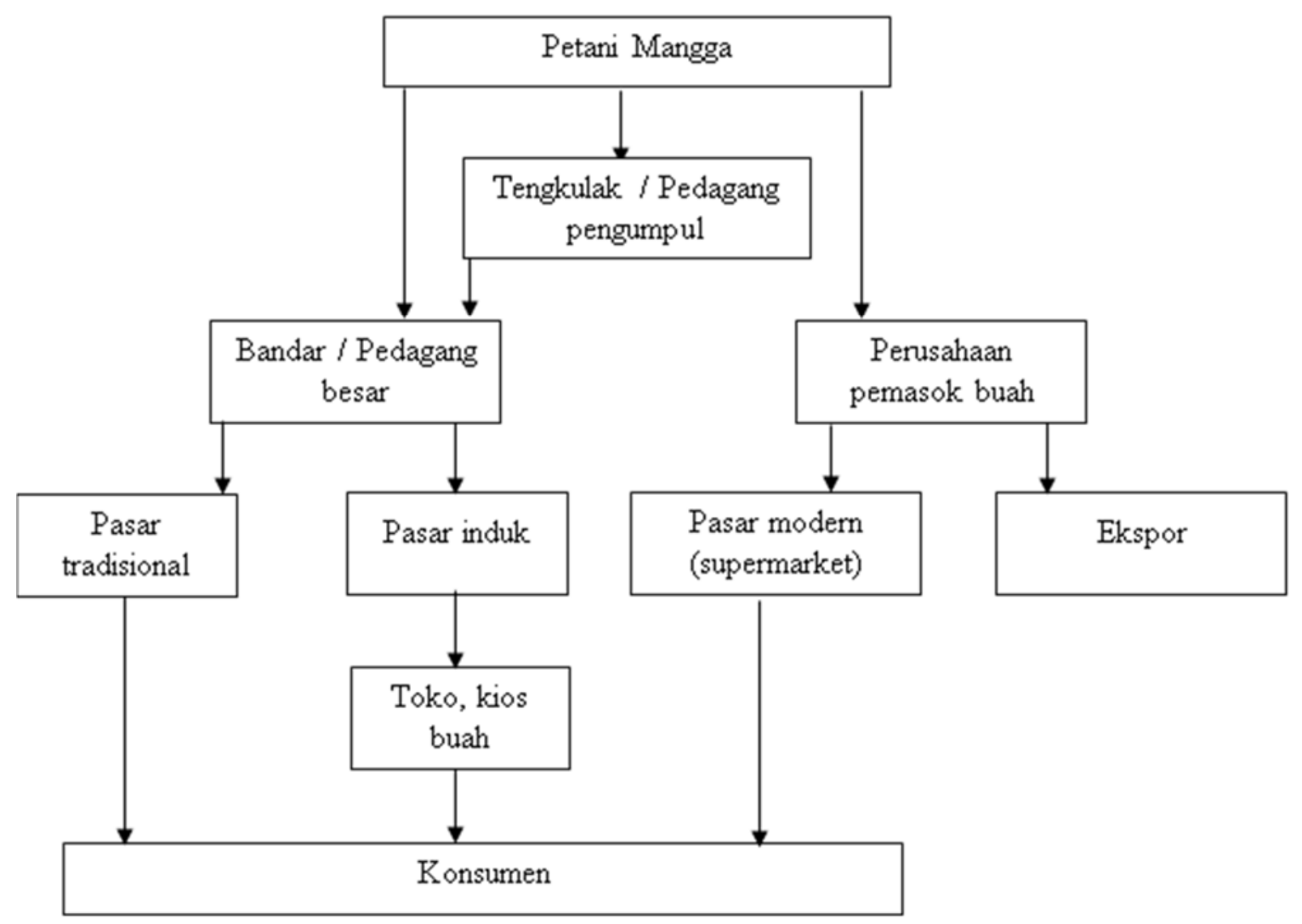

Gambar 1. Saluran Pemasaran Mangga di Kabupaten Indramayu

juga berperan sebagai pedagang pengumpul. Petani golongan ini melakukan kegiatan sortasi dan grading sebelum menyalurkan mangga ke pasar modern ataupun ke ekportir dan hanya mangga Grade A yang diterima oleh pasar ini.

\section{Faktor-faktor yang Mempengaruhi Keputusan Petani Mangga dalam Pemilihan Pasar di Kabupaten Indramayu}

Berdasarkan hasil analisis menggunakan SPSS, diketahui nilai Nagelkerke R Square adalah 0,675 hal ini menunjukkan bahwa kemampuan variabel independen dalam menjelaskan variabel dependen adalah $67,5 \%$ dan terdapat $32,5 \%$ faktor lain di luar model yang menjelaskan variabel dependen. Sementara itu nilai overall percentage adalah $94,6 \%$ yang berarti ketepatan model penelitian ini adalah sebesar $94,6 \%$.

Besarnya pengaruh variabel independen terhadap variabel dependen ditunjukkan dengan nilai Exp (B) atau disebut Odds Ratio (OR). Pada Tabel 4 dapat dilihat variabel, frekuensi mengikuti kegiatan pelatihan, akses informasi mengenai pemasaran mangga, akses informasi mengenai harga mangga, syarat kualitas produk dan keterikatan pada lembaga tertentu berpengaruh nyata terhadap keputusan petani mangga dalam pemilihan pasar di Kabupaten Indramayu.

Hasil analisis menunjukkan, variabel karakteristik individu petani seperti umur, pengalaman usahatani dan jumlah pohon yang dimiliki tidak berpengaruh terhadap keputusan petani dalam memilih pasar. Keputusan petani dalam memilih pasar lebih dipengaruhi oleh tingkat pendidikan petani. Tingkat pendidikan responden berpengaruh nyata terhadap keputusan petani mangga dalam pemilihan pasar di Kabupaten Indramayu dengan odd ratio 0,614 , artinya petani dengan tingkat pendidikan berpeluang 0,614 kali lebih tinggi untuk 
Tabel 4 Hasil analisis regresi logistik faktor-faktor yang mempengaruhi keputusan petani mangga dalam pemilihan pasar di Kabupaten Indramayu

\begin{tabular}{lrrr}
\hline \multicolumn{1}{c}{ Variabel } & B & \multicolumn{1}{l}{ Sig. } & \multicolumn{1}{c}{ OR } \\
\hline Umur & 0,373 & 0,169 & 0,435 \\
\hline Tingkat pendidikan & $\mathbf{0 , 4 8 8}$ & $\mathbf{0 , 0 2 6}$ & $\mathbf{0 , 6 1 4}$ \\
\hline Jumlah pohon & 0,009 & 0,176 & 0,991 \\
\hline Pengalaman usahatani & 0,088 & 0,244 & 0,916 \\
\hline Frekuensi mengikuti kegiatan penyuluhan & $\mathbf{3 , 2 6 5}$ & $\mathbf{0 , 0 1 2}$ & $\mathbf{2 6 , 1 6 8}$ \\
\hline Keanggotaan dalam kelompok tani (1=ya, 0=tidak) & 2,122 & 0,999 & 0,001 \\
\hline Bermitra dalam pemasaran (1=ya, 0=tidak) & 1,756 & 0,999 & 0,001 \\
\hline Akses informasi mengenai budidaya mangga & 1,255 & 0,202 & 3,509 \\
\hline Akses informasi mengenai pemasaran mangga & $\mathbf{2 , 3 3 4}$ & $\mathbf{0 , 0 9 9}$ & $\mathbf{3 , 1 9 7}$ \\
\hline Mendapatkan informasi mengenai harga mangga & 2,163 & 0,088 & 8,700 \\
(1= ya, 0= tidak) & & & \\
\hline Kondisi jalan ke kebun & 1,056 & 0,341 & 0,348 \\
\hline Kemudahan mengakses pasar & 1,130 & 0,169 & 3,096 \\
\hline Syarat kualitas produk (1=ya, 0=tidak) & $\mathbf{1 , 5 3 0}$ & $\mathbf{0 , 0 3 3}$ & $\mathbf{4 , 6 1 6}$ \\
\hline Persentase hasil panen yang berkualitas baik(grade A) & $\mathbf{0 , 0 2 2}$ & $\mathbf{0 , 0 3 1}$ & $\mathbf{0 , 9 7 8}$ \\
\hline Keterikatan pada lembaga tertentu (1=tidak, $\mathbf{0}=\mathbf{y a )}$ & $\mathbf{1 , 7 8 2}$ & $\mathbf{0 , 0 0 3}$ & $\mathbf{0 , 1 6 8}$ \\
\hline
\end{tabular}

menjual hasil panennya ke pasar formal. Damihartini dan Jahi (2005) menyebutkan pembangunan pertanian berawal dari kualitas petani sebagai pelaku utama, dimana pendidikan berkorelasi dengan kualitas petani. Mardikanto (1993) menjelaskan tingkat pendidikan mempengaruhi cara dan pola pikir petani dalam menjalankan usahataninya. Lebih lanjut Welter dan Smallbone (2011) menyebutkan tingkat pendidikan yang baik dapat mendorong seseorang untuk lebih mudah beradaptasi dengan lingkungannya. Tingkat pendidikan juga berhubungan dengan kemampuan seseorang dalam menyesuaikan diri dengan struktur kelembagaan yang berubah ubah dan membangun kontak bisnis dan jaringan sosial (Zainura et al, 2016). Tingkat pendidikan sebagian besar responden yang tergolong rendah membuat petani memilih menjual mangga nya ke pasar yang paling mudah untuk dijangkau.

Frekuensi mengikuti kegiatan penyuluhan berpengaruh nyata terhadap keputusan petani mangga dalam pemilihan pasar di Kabupaten Indramayu dengan odd ratio 26,168 , artinya petani yang lebih sering mengikuti kegiatan penyuluhan berpeluang26,168 kali lebih tinggi untuk menjual hasil panennya ke pasar formal.
Undang-Undang No 16 tahun 2016 tentang Sistem Penyuluhan Pertanian, Perikanan dan Kehutanan ( SP3K) menyebutkan bahwa penyuluhan adalah proses pembelajaran bagi pelaku utama serta pelaku usaha agar mau dan mampu menolong dan mengorganisasikan dalam mengakses informasi informasi pasar, teknologi, permodalan dan sumber daya lainnya sebagai upaya untuk meningkatkan produktivitas, efisiensi usaha, pendapatan dan kesejahteraannya serta meningkatkan kesadaran dalam pelestarian fungsi lingkungan hidup. Meskipun sebagian besar petani tidak pernah mengikuti kegiatan penyuluhan, namun petani berpendapat bahwa kegiatan penyuluhan dapat memberikan pengetahuan dan keterampilan pada petani mengenai teknis budidaya dan informasi pasar sehingga dapat membantu petani untuk memenuhi permintaan pasar. Lebih lanjut Anantayu (2011) menjelaskan bahwa kegiatan penyuluhan dapat meningkatkan motivasi petani serta meningkatkan kapastitas individu petani sekaligus kapastitas kelembagaan petani agar petani dapat mandiri dalam mencari pasar dan informasi yang sesuai dengan kebutuhannya.

Keanggotaan dalam kelompok tani dan kemitraan dalam pemasaran tidak 
berpengaruh nyata terhadap keputusan petani dalam memilih pasar di Kabupaten Indramayu. Sebagian besar petani memang tidak tergabung dalam kelompok ataupun kemitraan pemasaran (Tabel 2). Nuryanti dan Swastika (2011) mengungkapkan kelompok tani secara filosofis dibentuk berdasarkan kepentingan bersama dalam berusaha tani, dalam hal pengadaan sarana produksi dan pemasaran hasil secara kolektif untuk memperkuat posisi tawar petani. Sebagian besar petani responden memilih menjual sendiri hasil panennya kepada tengkulak atau bandar dan tidak bermitra secara formal dalam pemasaran mangga. Ton, et al (2018); Bellemere dan Novak (2017) menyebutkan bahwa kemitraaan idealnya didasarkan pada perjanjian kerjasama secara tertulis. Hasil penelitian Ton et al (2018) menunjukkan petani kecil dapat memperoleh keuntungan dari kontrak penjualan, dalam $61 \%$ kasus petani yang bermitra dapat memperluas kepemilikan lahan atau asset lainnya dibandingkan dengan petani yang tidak bermitra, namun petani golongan bawah jarang terlibat dalam kemitraan. Di lokasi penelitian hanya sebagian kecil petani yang bermitra dengan supplier atau perusahaan pemasok buah segar yang menyalurkan mangga petani ke pasar modern dan pasar eksport.

Akses informasi mengenai pemasaran mangga berpengaruh nyata terhadap keputusan petani mangga dalam pemilihan pasar di Kabupaten Indramayu dengan odd ratio 3,197 artinya petani yang lebih mudah mendapatkan informasi mengenai peluang pasar mangga berpeluang 3,197 kali lebih tinggi untuk menjual hasil panennya ke pasar formal. Informasi mengenai kondisi pasar akan membantu petani dalam memutuskan kemana menjual hasil panennya dengan harga yang lebih menguntungkan. Penelitian Sulistyowati et al (2013) juga menunjukkan sistem penjualan mangga dipengaruhi oleh sistem pembiayaan dan akses terhadap informasi dengan korelasi positif.Sebagian besar petani tidak merasa kesulitan dalam memperoleh informasi mengenai pasar yang dituju. Petani selama ini merasa bahwa mereka lebih mudah mendapatkan informasi pasar dari pedagang pengumpul, meskipun dalam hal informasi harga petani kurang memiliki daya tawar dalam menentukan harga. Li (2016) menjelaskan pada kasus di Cina, petani kecil berada pada posisi yang lemah dalam penentuan harga produk pertanian. Skala usaha yang kecil, informasi yang asimeti dan kemampuan negosiasi yang lemah menjadi penyebab kurangnya daya tawar petani di pasar. Meskipun demikian sebagian besar petani lebih memilih menjual hasil panennya pada pedagang pengumpul, kedekatan dengan pedagang, kemudahan dalam menjual dan syarat yang mudah membuat petani lebih memilih berhubungan dengan lembaga pemasaran informal.

Syarat kualitas produk berpengaruh nyata terhadap keputusan petani mangga dalam pemilihan pasar di Kabupaten Indramayu dengan odd ratio 4,617 artinya petani yang dapat memenuhi syarat kualitas produk yang diinginkan pasar berpeluang 4,617 kali lebih tinggi untuk menjual hasil panennya ke pasar formal. Hal ini juga sejalan dengan temuan petani yang menghasilkan hasil panen berkualitas baik lebih tinggi (Grade A) lebih berpeluang 0,978 kali untuk menjual produknya ke pasar formal. Pasar modern dan pasar eksport memang hanya menerima produk mangga dengan kualitas terbaik. Sebagian petani cenderung menghindari tujuan pasar yang mengharuskan standar kualitas tertentu. Banyak petani yang belum melakukan pemeliharaan pohon manganya secara intensif, yang tentunya berpengaruh terhadap kualitas dan kuantitas buah mangga yang dihasilkan. Melihat kondisi tersebut, petani perlu dilatih untuk memiliki jiwa wirausaha dengan menghasilkan produk yang diinginkan pasar, bukan sekedar menjual apa yang mereka hasilkan agar petani lebih dapat bersaing di pasar (Corsi et al, 2017; Syafiuddin \& Jahi, 2007). 
Keterikatan petani terhadap sumber pembiayaan tertentu berpengaruh terhadap keputusan petani dalam pemilihan pasar. Sebagian petani memiliki keterikatan bantuan sarana produksi pertanian sehingga petani harus menjual hasil panennya kepada pemberi modal. Fakta yang menarik adalah sebagian petani $(38,46 \%)$ menggunakan lembaga keuangan formal (Bank) untuk memperoleh pinjaman modal usaha, dan pilihan mereka untuk menjual hasil panennya pada tengkulak atau bandar bukanlah karena keterikatan modal namun berdasarkan kemudahan akses dan kedekatan interpersonal dengan tengkulak atau bandar. Hal ini menunjukkan bahwa bagi sebagian besar petani keberadaan lembaga pemasaran informal dirasakan menguntungkan, selain karena kemudahan akses dan syarat penjualan hasil panen, jangka waktu pembayaran yang relatif cepat dan kedekatan petani dengan tengkulak atau bandar juga menjadi pertimbangan petani dalam memilih pasar.

\section{Kesimpulan}

Sebagian besar petani menjual mangganya pada lembaga pemasaran informal (pedagang pengumpul). Keputusan petani dalam memilih pasar dipengaruhi oleh tingkat pendidikan, frekuensi mengikuti kegiatan penyuluhan, akses informasi mengenai pemasaran mangga, kemudahan syarat memasuki pasar, presentase hasil panen yang berkualitas baik serta keterikatan petani terhadap sumber pembiayaan tertentu. Selain faktor-faktor tersebut, kedekatan petani dengan pedagang pengumpul menjadi pertimbangan tersendiri bagi petani dalam memilih pasar.

Kegiatan penyuluhan dirasakan penting untuk meningkatkan pengetahuan dan keterampilan petani mengenai teknis budidaya mangga, perlakuan pasca panen hingga pemasaran agar petani dapat menghasilkan mangga yang berkualitas dan mendapatkan harga yang lebih baik. Dari segi kelembagaan, keberadaan kelompok tani perlu diaktifkan kembali sesuai fungsi kelompok tani sebagai wahana belajar, wahana kerjasama dan unit produksi agar petani lebih berdaya dan meningkatkan daya tawar petani di pasar.

\section{Ucapan Terima Kasih}

Terima kasih kepada Kemenristek Dikti yang telah membiayai penelitian ini dalam skema PUPT (Penelitian Unggulan Perguruan Tinggi) tahun anggaran 2017.

\section{Daftar Pustaka}

Abafita, J., Atkinson, J., Kim, C.S. 2016. Smallholder Commercialization in Ethiopia : Market Orientation and Participation. International Food Reserarch Journal, 23 (4) : 179718907.

Anantayu, S. 2011. Kelembagaan Petani : Peran dan Strategi Peningkatan Kapasitasnya. SEPA, 7(2) : 102-109.

Anugrah, I.S. 2009. Mendudukan Komoditas Mangga Sebagai Unggukan Daerah dalam Suatu Kebijakan Sistem Agribisnis Upaya Menyatukan Dukungan Kelembagaan Bagi Eksistensi Petani. Jurnal Analisis Kebijakan Pertanian, 7(2) : 189-211.

Badan Pusat Statistik. 2015. Produksi Mangga di Wilayah Sentra di Jawa Barat. Data Statistik Tanaman Pangan dan Hortikultura.

Bellemare, M.F., Novak, L. 2017. Contract Farming and Food Security. American Journal of Agricultural Economics, 99(2) : 357-378.

Barret, C.B., Carter, M.R., Timmer, C.P. 2010. A Century-Long Perspective on Agricultural Development. Journal Agri Economic, 92(2) : 447468.

Caswell, M., Fuglie, K., Ingram, C., Jans, S., Kascak, C. 2001. Adoption of Agricultural Production Practices : Lessons Learned from the US Departement of Agriculture Area Studies Project. US Departement of Agriclture, Resource Economics 
Division, EconomicResearch Service. Agriculture Economic Report No. 79. Washington DC.

Collier, P., Dearcon, S. 2014. African Agriculture in 50 Years : Smallholders in a Rapidly Changing World. Economic Trans. Afr, 63(1) : 92-101.

Corsi, S., Marchisio, L.N., Orsi, L. 2017. Connecting Smallholder farmers to Lokal Markets : Drivers of Collective Action, Land Tenur and Food Security in East Chad. Land Use Policy, 68(2017) : 39-47.

Damihartini, R.S., Jahi, A. 2005. Hubungan Karakteristik Petani dengan Kompetensi Agribisnis pada Usahatani Sayuran di Kabupaten Kediri Jawa Timur. Jurnal Penyuluhan, 1(1) : 41-48.

Farina, E.M.M.Q., Reardon, T. 2000. Agrifood Grades and Standars in the Extended Mercosur : Their Role in the Changing Agrifood System. American Journalof Agro Economics, 82(5) :1170-1176.

Li, Dexuan. 2016. Pricing Power of Agricultural Products under the Background of Small Peasant Management and Information Asymmetry. Asian Agricultural Research, 8(3) : 12-16.

Mardikanto, T. 1993. Penyuluhan Pembangunan Pertanian. Surakarta : Sebelas Maret University Press.

Melesse, Kumilachew A. 2016. Commercial Behaviour of Smallholder Potato Producers : The Case of Kombolchaworeda, Eastern Part of Ethiopia. Journal Economics of Agriculture, 13(63) : 159-173.

Mosher, A.T. 1991. Menggerakkan dan Membangun Pertanian. Jakarta : CV Yasaguna.

Nakano, Y., Tsusaka, T.W., Aida, T., Pede, V.O. 2018. Is Farmer to Farmer Extension Effective? The Impact of Training on Technology Adoption and Rice Farming Productivity in
Tanzania. World Development, 105(2018) : 336-351.

Natawidjaja, Ronnie. S. 2007. Horticultural

Producers and Supermarket

Development in Indonesia. The

World Bank. Report No 38543-ID.

Natawidjadja, Ronnie S. 2010. Farmer's Search in Agricultural Market. SOCA, 10(2) : 141- 153.

Natawidjadja, Ronnie S. 2012. Understanding How Informality Works in Reality : The Case of Horticulture Sector in Indonesia. Paper at Meeting Smaal Scale Farmers in Their Markets : Understanding and Improving the Institutions ang Governannce of Inforal Agrifood Tradeheld in Amsterdam November 29-30, 2012.

Noor, A. 2013. Perlindungan terhadap Pasar

Tradisional di Tengah Ekspansi Pasar Ritel Modern. Jurnal Economica, 6(2) : 107-120.

Nuryanti, S. Swastika, D.K.S. 2011. Peran Kelompok Tani dalam Penerapan Teknologi Pertanian. Forum Penelitian Agro Ekonomi, 29(2) : 115-128.

Pusat Data dan Sistem Informasi Pertanian. 2014. Outlook Komoditi Mangga. Jakarta : Sekretariat Jenderal Kementrian Pertanian.

Ramadhani, W., Rasmikayati, E. 2017. Pemilihan Pasar Petani Mangga serta Dinamika Agribisnisnya di Kecamatan Panyingkiran Kabupaten Majalengka Provinsi Jawa Barat. Jurnal Mimbar Agribisnis, 3(2) : 185202

Sulistyowati, L., Rasmikayati, E., Budiman, M.A., Saidah, Z. 2014. Pengembangan Kemitraan Usaha dalam Upaya Meningkatkan Komersialisasi dan Pendapatan Petani Mangga. Laporan Penelitian Universitas Padjadjaran.

Sulistyowati, L., Natawidjaja, R.S., Saidah, Z. 2013. Faktor-faktor Sosial Ekonomi yang Mempengaruhi Keputusan Petani Mangga Terlibat 
dalam Sistem Informal dengan Pedagang Pengumpul. Jurnal Sosiohumaniora, 15(3) : 285-293.

Syafiuddin., Jahi, A. 2007. Hubungan Karakteristik Individu dengan Kompetensi Wirausaha Petani Rumput Laut di Sulawesi Selatan. Jurnal Penyuluhan, 3(1) : 35-42.

Ton, G., Vellema, W., Desiere, S., Weituschat, S., D’Haese, M. 2018. Contract Farming for Improving Smallholder Incomes : What Can We Learn from Effectiveness Studies?. World Development, 104(2018) : 4664.

Welter, F., Smallbone, D. 2011. Institutional Perspective on Entrepreneurial Behavior in Challenging Environments. Journal of Small Business Management, 49(1) : 107125.

Zainura, U., Kusnasi, N., Burhanuddin. 2016. Perilaku Kewirausahaan Petani Kopi Arabika Gayo di Kabupaten Bener Meriah Provinsi Aceh. Jurnal Penyuluhan, 12(2) : 126-143. 